\title{
Gastrin studies in gastric ulcer
}

\author{
M. G. KORMAN, C. SOVENY, AND J. HANSKY \\ From Monash University Department of Medicine, Prince Henry's Hospital, St Kilda Road, Melbourne
}

SUMMARY Basal serum gastrin in 40 patients with benign gastric ulcer was $103 \pm 10 \cdot 7 \mathrm{pg} / \mathrm{ml}$, a level significantly higher than corresponding estimations in normal subjects and patients with duodenal ulcer.

Following stimulation by a protein meal, a mean rise of $124 \mathrm{pg} / \mathrm{ml}$ was achieved at 75 minutes and prior atropinization induced a rise of $208 \mathrm{pg} / \mathrm{ml}$ at 90 minutes. Insulin hypoglycaemia produced a rise of $63 \mathrm{pg} / \mathrm{ml}$ which was not significantly changed with concomitant neutralization of gastric contents.

These results suggest that patients with gastric ulcer have higher basal gastrin levels than normal and this is probably related to the lowered antral acidity. In addition, the protein meal and insulin hypoglycaemia responses suggest an increased antral $G$ cell mass and the possibility of additional gastrin release from sites outside the antrum.

It is doubtful whether the relative hypergastrinaemia has an aetiological role in gastric ulcer but it may have a role in the maintenance of gastric ulcer.

Although the aetiology of benign gastric ulcer is unknown, factors ranging from duodenal regurgitation to antral stasis and hormone overproduction have been proposed. Korman, Soveny, and Hansky (1971a) have demonstrated that basal gastrin levels are higher in patients with gastric ulcer than in normals or patients with duodenal ulcer. They suggested that the fasting levels were high because of a decrease in the acid milieu of the antrum with less inhibition of gastrin release.

It has been proposed that the serum gastrin response to either food or insulin stimulation reflects the $\mathrm{G}$ cell mass of the antrum (Korman et al, 1971a; Hansky, Korman, Cowley, and Baron, 1971a). The serum gastrin response to vagal stimulation by insulin hypoglycaemia and food stimulation has been assessed in a group of patients with a benign lesser curve gastric ulcer in order to determine the pattern of gastrin release and to ascertain the functional $\mathrm{G}$ cell mass.

\section{Material and Methods}

Forty patients, 20 females and 20 males, with gastric ulcer were studied. All patients had recent symptoms consistent with this diagnosis, and radiology, cytology, and endoscopy suggested a benign lesser

Received for publication 28 November 1971. curve lesion. Age ranged from 24 to 80 years with a mean of 51 years. After an overnight fast, peripheral venous blood was drawn for gastrin estimation.

Five patients were then further investigated. A 19gauge needle was inserted into a forearm vein and patency ensured by frequent flushing with a solution of heparin 1000 units in $20 \mathrm{ml}$ of $0.9 \%$ sodium chloride. Each patient, following an overnight fast, had gastrin measured after a protein meal with and without a prior intramuscular injection of atropine sulphate $(0.6 \mathrm{mg}$ at -30 minutes) and also in response to insulin hypoglycaemia $(0.2$ units per $\mathrm{kg}$ body weight intravenously).

Two patients also had their gastrin response studied to insulin hypoglycaemia and concomitant intragastric neutralization with sodium bicarbonate. At zero time the stomach was aspirated and $50 \mathrm{ml}$ ( 25 m-equiv) of sodium bicarbonate instilled rapidly via a nasogastric tube (positioned fluoroscopically to ensure placing of the tip in the antrum) followed by the constant infusion of bicarbonate solution at a rate of $100 \mathrm{ml}$ ( $50 \mathrm{~m}$-equiv) per hour for two hours. Insulin, $\mathbf{0 . 2}$ units per $\mathrm{kg}$ body weight, was injected intravenously at zero time.

In all these investigations blood was drawn at $-60,-30,0,15,30,45,60,75,90,105$, and 120 minutes for gastrin, and where applicable, glucose estimation. Each study was performed on separate days.

The methods of these studies are identical to those 
undertaken previously in both normal subjects and patients with duodenal ulcer (Korman, Soveny, and Hansky, 1971b; Korman et al, 1971a; Hansky et al, 1971a). Comparisons of the rise in gastrin above basal levels could thus be made.

Blood glucose was estimated using the glucose oxidase method on an autoanalyser (Wincey and Marks, 1961). Serum gastrin was estimated in duplicate by immunoassay as previously described (Hansky and Cain, 1969; Hansky, Soveny, and Korman, 1971b).

Statistical analysis was by use of Student's $t$ test for comparison of group means (Snedecor and Cochran, 1968).

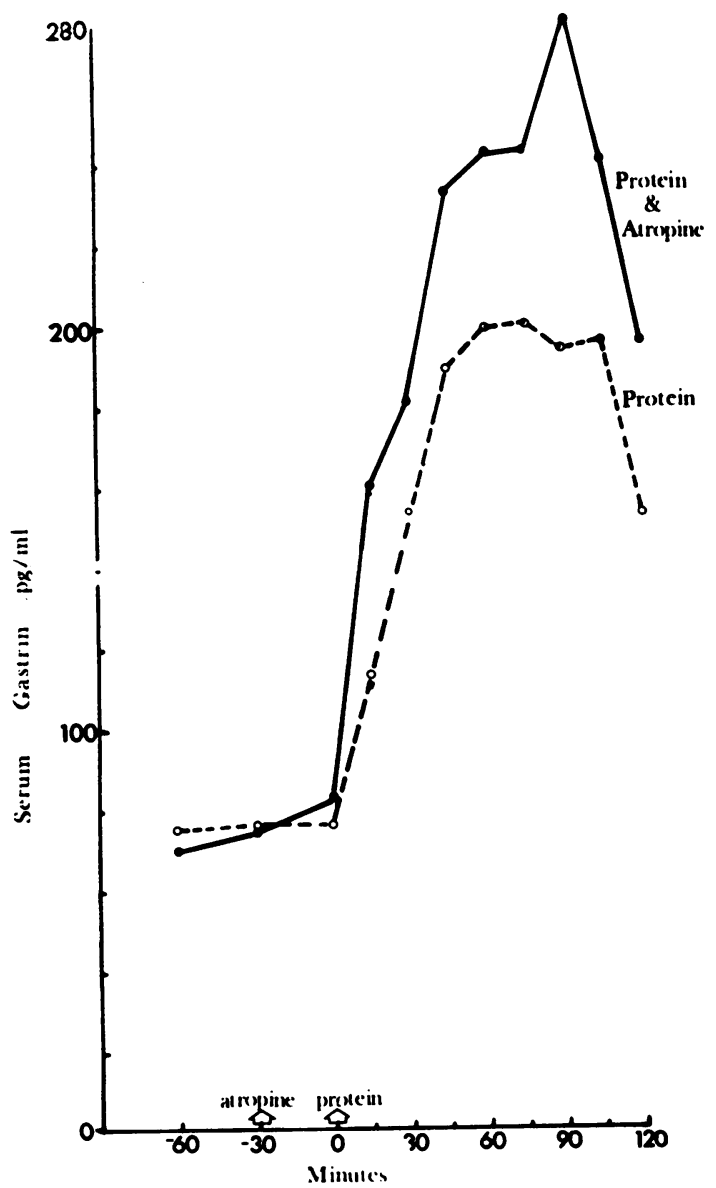

Fig. 1 Serum gastrin response to protein meal stimulation with and without the prior injection of $0.6 \mathrm{mg}$ atropine sulphate intramuscularly in five patients with gastric ulcer.
Results

The mean \pm SEM basal gastrin for the gastric ulcer patients was $103 \pm 10.7 \mathrm{pg} / \mathrm{ml}$ which is significantly higher $(P<0.0005)$ than levels previously reported for both duodenal ulcer $(16 \pm 1.5 \mathrm{pg} / \mathrm{ml}, 72$ patients $)$ and normals ( $32 \pm 4.3 \mathrm{pg} / \mathrm{ml}, 93$ subjects).

Figure 1 shows the response to a protein meal with and without prior atropine in five patients with gastric ulcer. With protein alone there is a significant rise from a mean basal level of $77 \pm 5 \cdot 1 \mathrm{pg} / \mathrm{ml}$ to a peak of $201 \pm 21.8 \mathrm{pg} / \mathrm{ml}$ at 75 minutes $(\mathrm{p}<0.025)$. With a protein meal and a prior injection of atropine, serum gastrin rises significantly from $73 \pm 7.5 \mathrm{pg} / \mathrm{ml}$ to $281 \pm 25.0 \mathrm{pg} / \mathrm{ml}$ at 90 minutes $(\mathrm{P}<0.0005)$.

The serum gastrin and blood glucose response to insulin hypoglycaemia in five patients is shown in Figure 2. Serum gastrin rose significantly from a basal level of $72 \pm 6.6 \mathrm{pg} / \mathrm{ml}$ to $135 \pm 23.1 \mathrm{pg} / \mathrm{ml}$ at 30 minutes after insulin $(P<0.025)$.

Figures $3 \mathrm{a}$ and $3 \mathrm{~b}$ compare the individual gastrin responses in two patients to insulin hypoglycaemia with and without intragastric neutralization with sodium bicarbonate. With insulin alone, there is an absolute rise above basal levels of $101 \mathrm{pg} / \mathrm{ml}$ and $58 \mathrm{pg} / \mathrm{ml}$ respectively, which increased to $130 \mathrm{pg} / \mathrm{ml}$ and $74 \mathrm{pg} / \mathrm{ml}$ with insulin and intragastric bicar-

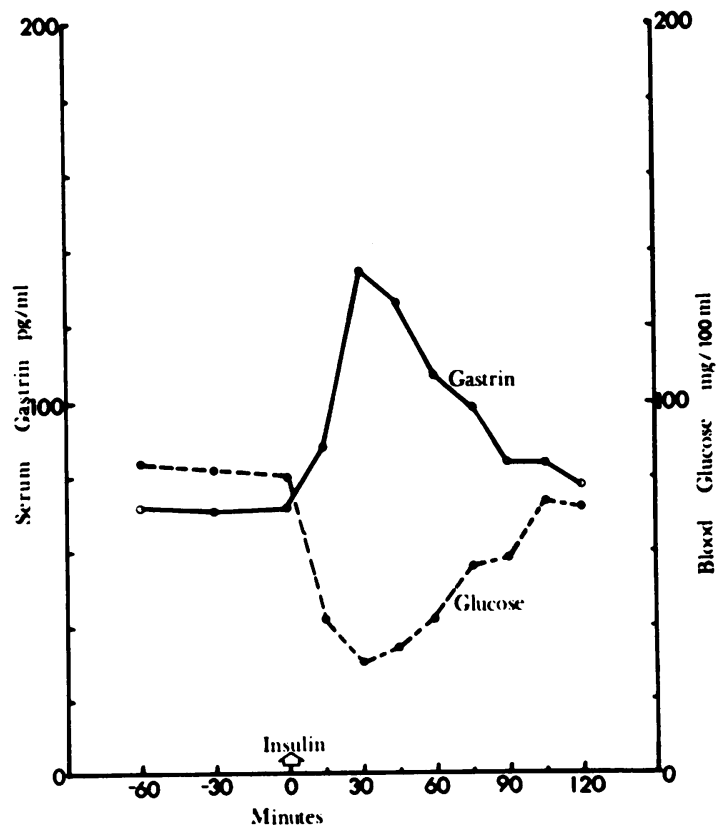

Fig. 2 Serum gastrin and blood glucose response to insulin hypoglycaemia in five patients with gastric ulcer. 


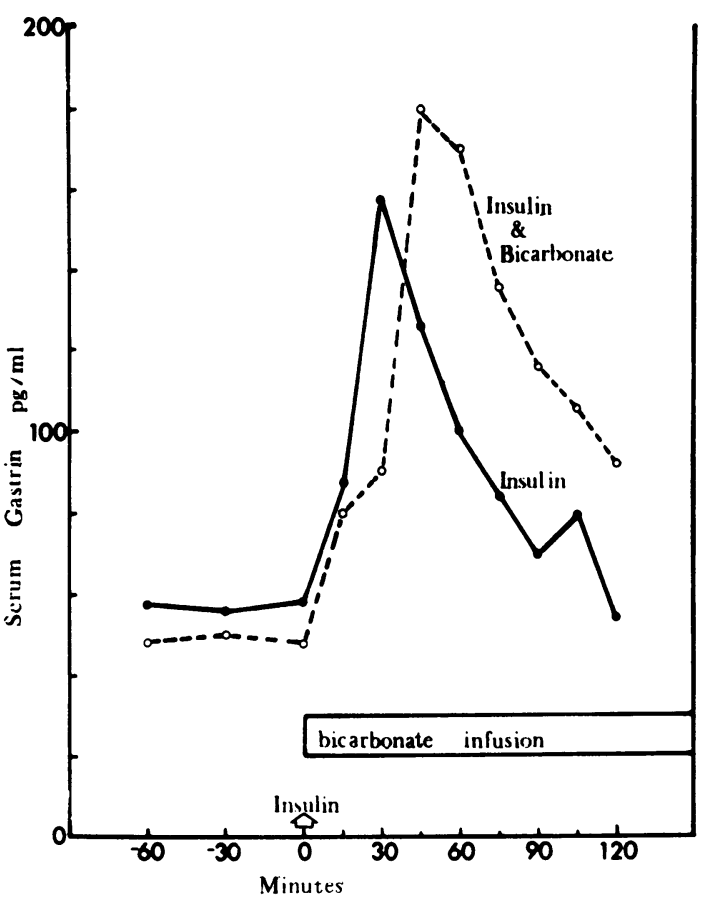

Fig. 3a

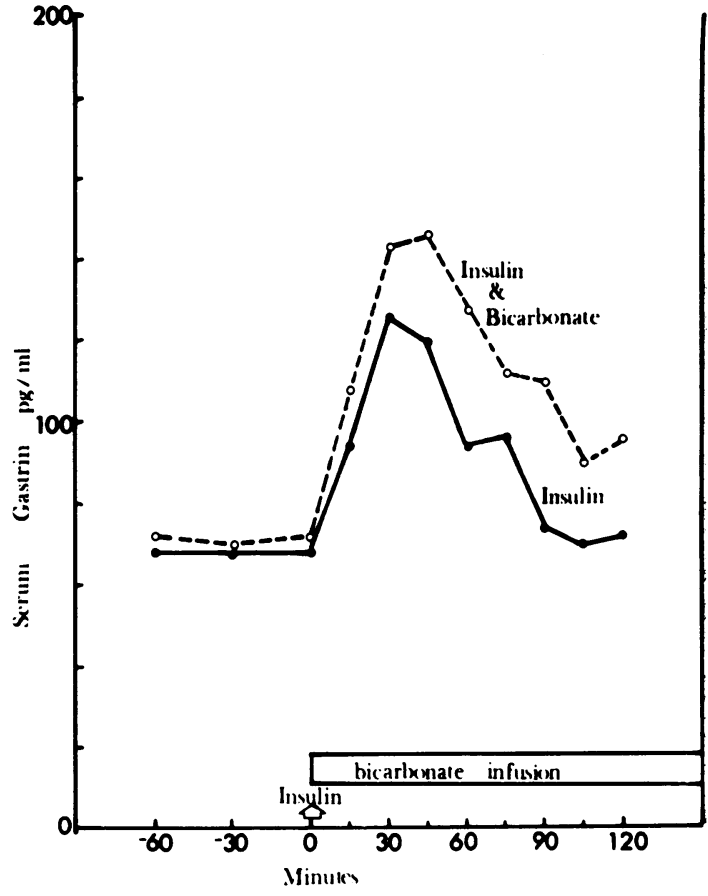

Fig. 3b

Fig. 3a and 3b Serum gastrin response to insulin hypoglycaemia with and without concomitant bicarbonate neutralization in two patients with gastric ulcer.

bonate. The increased response to insulin and bicarbonate neutralization is not significantly different to that obtained with insulin alone.

\section{Discussion}

The present results permit discussion about the basal serum gastrin, the functional $\mathrm{G}$ cell mass, the origin of gastrin, and the role of gastrin in gastric ulcer.

BASAL SERUM GASTRIN

The results indicate that basal serum gastrin is higher in gastric ulcer than in either normal control subjects or patients with duodenal ulcer. This raised basal serum gastrin is probably the result of decreased inhibition of release of antral gastrin, as the milieu in the antrum is less acid than in patients with duodenal ulcer or normal controls (Korman et al, 1971a). Another contributing factor may be based on Dragstedt's (1969) hypothesis of decreased antral motility and antral stasis with consequent stimulation of gastrin release.
FUNCTIONAL G CELL MASS

The protein meal and insulin hypoglycaemia stimulating studies suggest that the functional $G$ cell mass is increased in patients with gastric ulcer. Korman et al (1971a) and Hansky et al (1971a) proposed that protein meal studies and insulin hypoglycaemia combined with intragastric acid neutralization provide a measure of the functional $G$ cell mass. Although the absolute rise in serum gastrin of $124 \mathrm{pg} / \mathrm{ml}$ following a protein meal is higher in gastric ulcer patients than the corresponding results in normals or duodenal ulcer patients $(60$ and $77 \mathrm{pg} / \mathrm{ml}$ respectively), this could result from stimulation in the presence of diminished acid secretion and hence decreased inhibition of gastrin release. Under these circumstances a more accurate measure of the functional $\mathrm{G}$ cell mass is provided by studies with insulin hypoglycaemia combined with concomitant intragastric neutralization. Although only two patients were studied in this manner, the results suggest that the functional $G$ cell mass is slightly less than that in duodenal ulcer, but probably greater than that in normal subjects. 
ORIGIN OF GASTRIN IN GASTRIC ULCER

Korman, Hansky, and Scott (1972) have suggested that section of gastric and extragastric vagal fibres permits the release of gastrin in amounts above that achieved with neutralization of antral contents. They proposed that section of extragastric vagal fibres resulted in the decrease of an inhibitor to gastrin release. The present results with protein stimulation indicate that the prior administration of atropine sulphate results in an absolute rise in serum gastrin of $208 \mathrm{pg} / \mathrm{ml}$, the peak occurring at 90 minutes after the stimulus. This result is almost identical in terms of magnitude of response and time of occurrence to that achieved with the same experimental conditions in truncally vagotomized duodenal ulcer patients (Korman et al, 1972). As in the latter group, part of this gastrin may be derived from sites outside the antrum. Thus, although the major part of the circulating gastrin pool in gastric ulcer is antral in origin, it is proposed that part is derived from extraantral sources. The similarity of gastrin homeostasis in gastric ulcer and after truncal vagotomy thus offers some support for Dragstedt's hypothesis of decreased vagal activity in gastric ulcer.

ROLE OF GASTRIN IN GASTRIC ULCER

From these studies we cannot implicate gastrin as an aetiological factor in the genesis of gastric ulcer.
However, we can suggest that gastric mucosal damage by either duodenal reflux or some other mechanism allows uninhibited release of gastrin which may then facilitate the development of gastric ulceration.

This work was performed with the support of grants from the National Health and Medical Research Council of Australia.

References

Dragstedt, L. R. (1969). Peptic ulcer-an abnormality in gastric secretion. Amer. J. Surg., 117, 143-156.

Hansky, J., and Cain, M. D. (1969). Radioimmunoassay of gastrin in human serum. Lancet, $2,1388-1390$.

Hansky, J., Korman, M. G., Cowley, D. J., and Baron, J. H. (1971a). Serum gastrin in duodenal ulcer. II. Effect of insulin hypoglycaemia. Gut, 12, 959-962.

Hansky, J., Soveny, C., and Korman, M. G. (1971b). Effect of secretin on serum gastrin as measured by immunoassay. Gastroenterology, 61, 62-68.

Korman, M. G., Soveny, C., and Hansky, J. (1971 a). Serum gastrin in duodenal ulcer. I. Basal levels and effect of food and atropine. Gut, 12, 899-902.

Korman, M. G., Soveny, C., and Hansky, J. (1971b). Effect of food on serum gastrin evaluated by radioimmunoassay. Gut, 12, 619-624.

Korman, M. G., Hansky, J., and Scott, P. R. (1972). Serum gastrin in duodenal ulcer. III. Influence of vagotomy and pylorectomy. Gut, 13, 39-42.

Snedecor, G. W., and Cochran, W. G. (1968). Statistical Methods, 6th ed., pp. 91-119. Iowa State University Press, Ames, Iowa.

Wincey, C., and Marks, V. (1961). A micro method for measuring glucose using the AutoAnalyser and glucose oxidase. J. clin. Path., 14, 558-559. 